\title{
Effect of Antioxidants, Amino Acids and Plant Growth Regulators on in vitro Propagation of Rosa centifolia
}

\author{
Gulzar Akhtar 1,2*, Muhammad Jafar Jaskani ${ }^{2}$, Yasar Sajjad 3, Ahsan Akram 1 \\ ${ }^{1}$ Department of Horticulture, University College of Agriculture, University of Sargodha, Sargodha, Pakistan \\ ${ }^{2}$ Institute of Horticultural Sciences, University of Agriculture, Faisalabad, Pakistan \\ ${ }^{3}$ Department of Environmental Sciences, COMSATS Institute of Information Technology, Abbottabad, Pakistan \\ *Corresponding author: Gulzar Akhtar, Department of Horticulture, University College of Agriculture, University of Sargodha, Sargodha, Pakistan. \\ Tel: +92-3216211912, Fax: +92-483703665,E-mail: Gulzar_butt1849@yahoo.com
}

Received: February 08, 2015; Revised: July 07, 2015; Accepted: December 12, 2015

Background: Rosa centifoliais commercially propagated by asexual means but in vitro propagation ensure the production of disease free and healthy plants and browning of explants creates hurdle in their multiplication.

Objectives: The aim was to reduce oxidative browning of shoots of $R$. centifolia in MS medium during in vitro propagation.

Materials and Methods: Axillary buds of $R$. centifolia were sterilized with $70 \%$ ethyl alcohol for 4 min and 5\% sodium hypochlorite for $2 \mathrm{~min}$ followed by three washing with sterilized double distilled water. In order to control oxidative browning, Ascorbic acid (100 mg.L $\left.\mathrm{L}^{-1}\right)$, citric acid (100 mg.L-1) and activated charcoal (3 g.L-1 $)$ were used while to control withering of shoots, different concentrations $\left(3.0 \mathrm{mg} . \mathrm{L}^{-1}, 6.0 \mathrm{mg} \cdot \mathrm{L}^{-1}, 9.0 \mathrm{mg} . \mathrm{L}^{-1}\right)$ of either glutamine, asparagine and proline were put into trial. Different concentrations of Benzyl aminopurine (BAP) and naphthalene acetic acid (NAA) were used for in vitro shoot and root formation.

Results: Minimum browning percentage (20\%) was achieved in the presence of activated charcoal $(3.0$ g.L.-1) and pretreatment of explants with running tap water. Asparagin $\left(9.0 \mathrm{mg} \cdot \mathrm{L}^{-1}\right)$ produced maximum shooting $(93 \%)$, minimum withering (6.67\%), and it took longer period (27 days) for shoots to wither. BAP $\left(3.0 \mathrm{mg} . \mathrm{L}^{-1}\right)+\mathrm{NAA}\left(0.5 \mathrm{mg} . \mathrm{L}^{-1}\right)$ was produced the highest number of shoots (1.63), in a shortest periods (9 days). For root production, NAA (1.5 mg.. $\left.\mathrm{L}^{-1}\right)+$ BAP $\left(0.5 \mathrm{mg} . \mathrm{L}^{-1}\right)$ reduced the time to 11 days with maximum number of roots $(4.33)$ and root length $(4.20 \mathrm{~cm})$.

Conclusions: The supplement of activated charcoal $\left(3.0\right.$ g.L $\left.\mathrm{L}^{-1}\right)$, a sparagin $\left(9.0 \mathrm{mg} . \mathrm{L}^{-1}\right)$ and combination of BAP and NAA in the MS medium is effective for in vitro propagation of $R$. centifolia.

Keywords: Activated charcoal; Browning; In vitro Propagation; Rosa centifolia

\section{Background}

Rose, a member of Rosaceae, has more than 150 species and 1400 cultivars (1). R. centifolia is famous among oil producing species of roses with 4.25 tons per year around the globe (2). R. centifolia is commercially propagated by asexual methods that are sucker, hard wood cutting, semi hard wood cutting, budding and grafting. Propagation by vegetative methods does not ensure healthy and disease-free plants, as opposed to tissue culture (3). Furthermore, Propagation of $R$. centifolia through cutting is not very successful. This is considered as the main hurdle in oil industry that requires a huge amount of flowers. In roses, micro propagation of axillary buds is the method of choice, using varieties of growth regulators $(4,5)$.

All woody plants including roses excretes phenolic compounds from their tissues which may cause browning of the media (6) that can result in cessation of growth or development, and ultimately death of the explants. Browning is one of the important factors, which limits the growth of rose's in vitro culture. Browning can be controlled by adding substances such as pharmaceutical grade polyvinyl pyrolidone (PVP), ascorbic acid and activated charcoal (7).

Here, antioxidants, amino acids and plant growth regulators were used to address tissue browning of $R$. centifolia and to develop a protocol of its in vitro propagation. Eventually, oil industry based on $R$. centifolia will benefit from such attempts.

\section{Objectives}

Focusing on problems related to propagation of $R$. 
centifolia, the present study was conducted to overcome problems of oxidative browning and withering that occurred during in vitro propagation by using antioxidants and amino acids.

\section{Materials and Methods}

\subsection{Preparation of Explants and MS Medium}

All three steps of this study were conducted in Plant Tissue Cell, Institute of Horticultural Sciences, University of Agriculture, Faisalabad, Pakistan. The axillary buds were used as the explants and were collected from field grown healthy plants of $R$. centifolia. The explants were first washed with tap water and disinfected sequentially with $70 \%$ (v/v) ethyl alcohol for 4 $\min$ and $5 \%(\mathrm{v} / \mathrm{v})$ sodium hypochlorite for $2 \mathrm{~min}$ followed by three times rinsing with sterilized double distilled autoclaved water. The explants were cultured on MS medium (8), containing 8 mg.L $\mathrm{L}^{-1}$ agar and 30 g.L $\mathrm{L}^{-1}$ sucrose with vitamins (Inositol $\left(100 \mathrm{mg} . \mathrm{L}^{-1}\right.$, Nicotinic acid (0.5 mg.L $\left.\mathrm{L}^{-1}\right)$ and Thiamine $\mathrm{HCl}\left(0.5 \mathrm{mg} . \mathrm{L}^{-1}\right)$. Test tubes were maintained at $25^{\circ} \mathrm{C}$ with $16 \mathrm{~h}$ photoperiod.

\subsection{Treatments for Control of Browning}

Ascorbic acid, citric acid and activated charcoal were used to control browning. Explants were divided in three sets, the first set of explants was washed with running tap water for $1 \mathrm{~h}$ and placed in medium containing activated charcoal ( 3 g.L $\left.\mathrm{L}^{-1}\right)$ while second and third sets of explant were pretreated by stirring in ascorbic acid (100 mg. $\left.\mathrm{L}^{-1}\right)$ and citric acid (100 mg. $\left.\mathrm{L}^{-1}\right)$ respectively for 1hand placed in simple medium (without activated charcoal).

\subsection{Treatments for Control of Withering}

Axillary buds were placed under running tap water for $1 \mathrm{~h}$, cultured in the MS medium containing 3.0 g.L.-1 activated charcoal, supplemented with different concentrations (3.0 mg.L $\left.\mathrm{L}^{-1}, 6.0 \mathrm{mg} . \mathrm{L}^{-1}, 9.0 \mathrm{mg} . \mathrm{L}^{-1}\right)$ of glutamine, asparagin or proline to control withering of explants after shoot formation. When shoots reached to the height of about $2 \mathrm{~cm}$, numbers of healthy shoots/withering $\%$ were recorded.

\subsection{Shoot and Root Induction}

Axillary buds were washed under running tap water for $1 \mathrm{~h}$ and cultured on the MS medium containing activated charcoal (3 g.L $\left.\mathrm{L}^{-1}\right), 0.09 \mathrm{mg} . \mathrm{L}^{-1}$ of asparagin, BAP (1.5 or $\left.3.0 \mathrm{mgL}^{-1}\right)$ alone and in combination with NAA $\left(0.5 \mathrm{mg} . \mathrm{L}^{-1}\right)$ for shoot formation. Data of number of days to initiate shoot, number of shoots, number of leaves and shoot length were recorded before transferring the shoots to rooting media.

After reaching $2 \mathrm{~cm}$ height, shoots were transferred into the MS medium supplemented with different concentrations of NAA (1.5 or $\left.3.0 \mathrm{mg} . \mathrm{L}^{-1}\right)$ alone or in combination with BAP $\left(0.5 \mathrm{mg} . \mathrm{L}^{-1}\right)$ for root induction. Number of days to induce roots, number of roots and root length were noted before shifting plantlets in small pots.

\subsection{Acclimatization of Plantlets}

Well-developed rooted shoots (15-20 cm in height) were transferred to square plastic pot containing peat moss, covered with polythene and placed in hardening room for acclimatization $\left(27^{\circ} \mathrm{C}, 12 \mathrm{~h}\right.$ photoperiod duration, 3000 foot-candles of light intensity). Plantlets were gradually acclimatized and exposed to greenhouse conditions.

All the experiments were conducted in completely randomized design (CRD). Each treatment had three replications and each replication had 12 explants. The treatment means were compared by applying the Least Significant Difference (LSD) test at $5 \%$ probability level.

\section{Results}

The lowest browning (20\%) was observed in the explants were washed under running tap water for $1 \mathrm{~h}$ and cultured in MS medium supplemented with activated charcoal (Figures 1 and 2). Pre-treatment of explants with ascorbic acid and citric acid solutions produced $40 \%$ and $33.33 \%$ browning, respectively. Maximum browning (93.33\%) was noticed in control (Figure 1). Withering of explants started after 27 days in medium supplemented with $9.0 \mathrm{mg} . \mathrm{L}^{-1}$ asparagin (Table 1 and Figure 2). MS media without any amino acid was the least effective to stop withering; it took 10

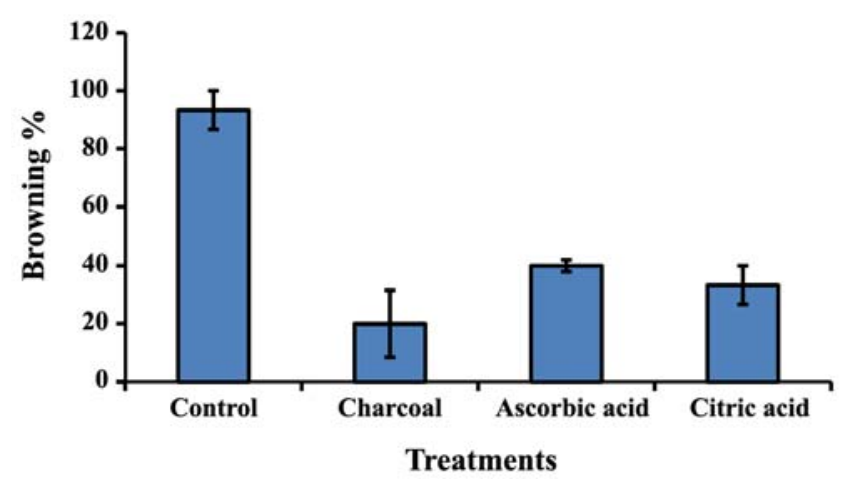

Figure 1. Effect of different treatments on browning of the MS medium 
A

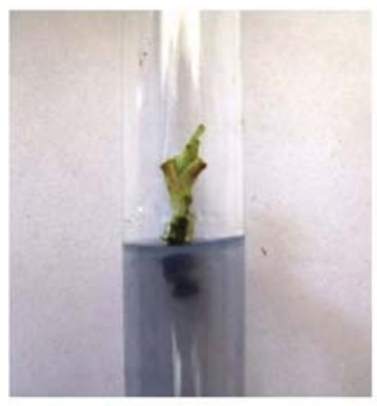

$\mathbf{E}$

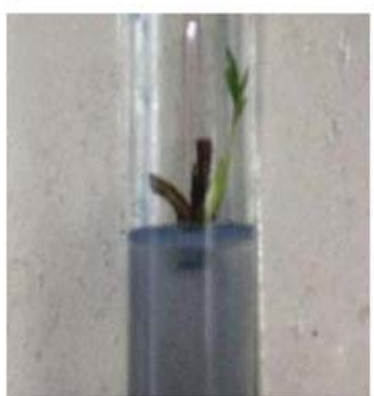

B

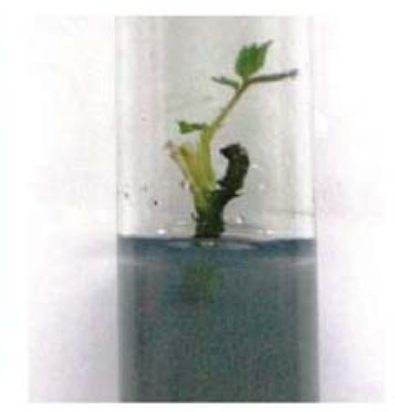

C

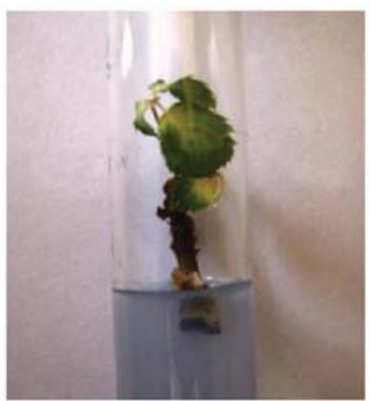

D

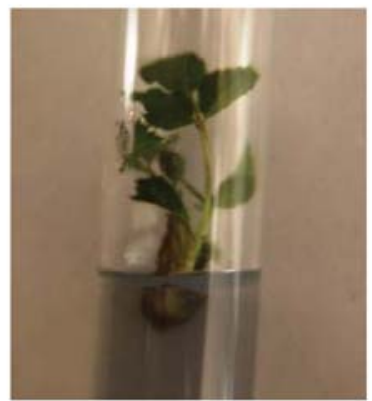

$\mathbf{F}$

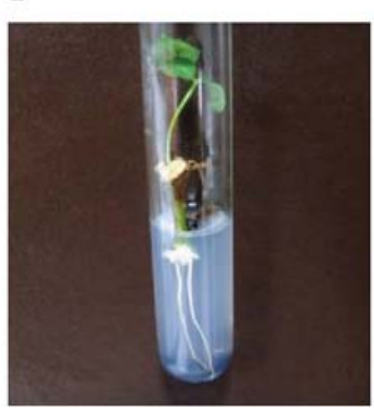

G

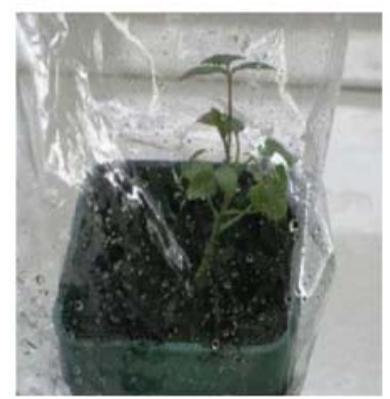

Figure 2. A: Browning of axillary buds in control MS medium, B: Browning of axillary buds in 3 g.L. L $^{-1}$ activated charcoal, C: Withering of in vitro shoot in control, D: Withering of in vitro shoot in 0.09 mg. $\mathrm{L}^{-1}$ Asparagin, E: In vitro Shoot formation, F: In vitro Root induction, G: Acclimatization

days. After which, glutamine $\left(6.0 \mathrm{mg} . \mathrm{L}^{-1}\right)$ ranked second least effective (12 days). The least withering $(6.67 \%)$ was observed in the presence of $9.0 \mathrm{mg} . \mathrm{L}^{-1}$ asparagin (Table 1). The highest withering (93.33\%) was observed in media with no amino acid (Table 1).

Asparagin at $9.0 \mathrm{mg} . \mathrm{L}^{-1}$ produced maximum healthy shoot (93.33\%) (Table 1). Minimum healthy

Table 1. Effect of amino acids on withering control of explants of Rosa centifolia

\begin{tabular}{lcccc}
\hline $\begin{array}{c}\text { Treatments } \\
\text { (mg.L-1) }\end{array}$ & $\begin{array}{c}\text { Withering } \\
(\%)\end{array}$ & $\begin{array}{c}\text { No. of days to } \\
\text { start withering }\end{array}$ & $\begin{array}{c}\text { Healthy } \\
\text { shooting (\%) }\end{array}$ \\
\hline Control & 0 & $93.33 \mathrm{~A}$ & $10.11 \mathrm{E}$ & $6.67 \mathrm{D}$ \\
Glutamine & 3.0 & $80.00 \mathrm{AB}$ & $25.11 \mathrm{AB}$ & $20.00 \mathrm{CD}$ \\
& 6.0 & $73.33 \mathrm{AB}$ & $11.56 \mathrm{DE}$ & $26.67 \mathrm{CD}$ \\
& 9.0 & $66.67 \mathrm{AB}$ & $22.22 \mathrm{ABC}$ & $33.33 \mathrm{CD}$ \\
Asparagin & 3.0 & $66.67 \mathrm{AB}$ & $20.11 \mathrm{ABC}$ & $33.33 \mathrm{CD}$ \\
& 6.0 & $33.33 \mathrm{CD}$ & $22.56 \mathrm{ABC}$ & $66.67 \mathrm{AB}$ \\
& 9.0 & $6.667 \mathrm{D}$ & $27.44 \mathrm{~A}$ & $93.33 \mathrm{~A}$ \\
Proline & 3.0 & $60.00 \mathrm{BC}$ & $17.00 \mathrm{CDE}$ & $40.00 \mathrm{BC}$ \\
& 6.0 & $53.33 \mathrm{BC}$ & $18.89 \mathrm{BCD}$ & $46.67 \mathrm{BC}$ \\
& 9.0 & $34.40 \mathrm{BC}$ & $18.90 \mathrm{BCD}$ & $47.20 \mathrm{BC}$ \\
LSD value & & 30.16 & 7.85 & 30.16 \\
P $\leq 0.05$ & & & & \\
\hline
\end{tabular}

Means with same letters are considered as non-significant shooting $(6.67 \%)$ was observed in the MS medium without amino acid followed by glutamine $3.0 \mathrm{mg} . \mathrm{L}^{-1}$ $(20.00 \%)$ and $6.0 \mathrm{mg} . \mathrm{L}^{-1}$ (26.67\%).

BAP in combination with NAA had significant effect on the presented variable results for shoot initiation (Table 2 and Figure 2). BAP (3.0 mg. $\left.\mathrm{L}^{-1}\right)$ in combination with $\left(0.5 \mathrm{mg} . \mathrm{L}^{-1}\right)$ NAA took minimum days (9) to produce shoots, while the MS medium without growth regulators took maximum days (17) to emerge shoots.

BAP (3.0 mg.L $\mathrm{L}^{-1}$ ) along with $0.5 \mathrm{mg} . \mathrm{L}^{-1}$ NAA formed maximum (1.63) number of shoots followed by BAP $3.0 \mathrm{mg} . \mathrm{L}^{-1}$ which produced 1.30 numbers of shoot (Table 2). MS medium without any plant growth regulator produced minimum (0.80) number of shoots. The highest number of leaves (2.63) was produced in the MS medium supplemented with BAP $3.0 \mathrm{mg}^{-\mathrm{L}^{-1}}$ in combination with $0.5 \mathrm{mg}$. $\mathrm{L}^{-1} \mathrm{NAA}$. The MS medium without any growth regulator produced minimum (1.8) number of leaves. Maximum shoot length $(5.9 \mathrm{~cm})$ was recorded in the MS medium containing BAP 3.0 mg. $\mathrm{L}^{-1}$ in combination with $0.5 \mathrm{mg} . \mathrm{L}^{-1} \mathrm{NAA}$ (Table 2). While BAP (3.0 mg.L $\left.\mathrm{L}^{-1}\right)$ alone and BAP $\left(1.5 \mathrm{mgL}^{-1}\right)$ along with $0.5 \mathrm{mg} . \mathrm{L}^{-1} \mathrm{NAA}$ produced $4.07 \mathrm{~cm}$ and $4.27 \mathrm{~cm}$ shoot length, respectively. The MS without 


\begin{tabular}{|c|c|c|c|c|c|c|c|c|c|c|}
\hline \multicolumn{2}{|c|}{$\begin{array}{l}\text { Treatments } \\
\left(\mathrm{mg}^{\left.-L^{-1}\right)}\right.\end{array}$} & \multirow[t]{2}{*}{$\begin{array}{l}\text { No. of days to } \\
\text { initiate shoots }\end{array}$} & \multirow[t]{2}{*}{$\begin{array}{l}\text { No. of } \\
\text { shoots }\end{array}$} & \multirow[t]{2}{*}{$\begin{array}{l}\text { No. of } \\
\text { leaves }\end{array}$} & \multirow{2}{*}{$\begin{array}{l}\text { Shoot } \\
\text { length } \\
(\mathrm{cm})\end{array}$} & \multirow{2}{*}{$\begin{array}{l}\text { Root } \\
\text { length } \\
(\mathrm{cm})\end{array}$} & \multirow[t]{2}{*}{$\begin{array}{l}\text { No. of } \\
\text { roots }\end{array}$} & \multirow[t]{2}{*}{$\begin{array}{l}\text { No. of days to } \\
\text { initiate roots }\end{array}$} & \multicolumn{2}{|c|}{$\begin{array}{l}\text { Treatments } \\
\left(\mathrm{mg}^{\left.-\mathrm{L}^{-1}\right)}\right.\end{array}$} \\
\hline$\overline{\text { BAP }}$ & NAA & & & & & & & & NAA & BAP \\
\hline Control & & & & & & & & & Control & \\
\hline 1.5 & & $17.03 \mathrm{~A}$ & $0.80 \mathrm{C}$ & $1.80 \mathrm{~B}$ & $3.83 \mathrm{D}$ & $3.26 \mathrm{C}$ & $2.00 \mathrm{C}$ & $17.10 \mathrm{~A}$ & 1.5 & \\
\hline 3.0 & & $16.53 \mathrm{~A}$ & $1.07 \mathrm{BC}$ & $2.03 \mathrm{~B}$ & $3.97 \mathrm{CD}$ & $3.27 \mathrm{C}$ & $2.03 \mathrm{C}$ & $17.07 \mathrm{~A}$ & 3.0 & \\
\hline 1.5 & 0.5 & $15.47 \mathrm{~B}$ & $1.30 \mathrm{AB}$ & $2.00 \mathrm{~B}$ & $4.07 \mathrm{BC}$ & $3.43 \mathrm{BC}$ & $2.13 \mathrm{C}$ & $16.40 \mathrm{~A}$ & 1.5 & 0.5 \\
\hline 3.0 & 0.5 & 16.30 AB & $1.00 \mathrm{BC}$ & $2.23 \mathrm{AB}$ & 4.27 B & $4.20 \mathrm{~A}$ & $2.63 \mathrm{~B}$ & $11.73 \mathrm{C}$ & 3.0 & 0.5 \\
\hline LSD value & & $9.23 \mathrm{C}$ & $1.63 \mathrm{~A}$ & $2.63 \mathrm{~A}$ & $5.90 \mathrm{~A}$ & $3.70 \mathrm{~B}$ & $4.43 \mathrm{~A}$ & $14.87 \mathrm{~B}$ & & \\
\hline$P \leq 0.05$ & & 1.57 & 0.35 & 0.34 & 0.47 & 0.24 & 0.37 & 1.84 & & \\
\hline
\end{tabular}

Means with same letters are considered as non-significant

any growth regulator produced minimum $(3.83 \mathrm{~cm})$ shoot length. BAP (1.5 mg. $\left.\mathrm{L}^{-1}\right)$ produced least (3.97 $\mathrm{cm})$ shoot length.

NAA (1.5 mg. $\left.\mathrm{L}^{-1}\right)$ along with BAP (0.5 mg.L $\left.\mathrm{L}^{-1}\right)$ induced roots within minimum 12 numbers of days (Table 2), while the MS medium without growth regulator took maximum numbers of days (17). Maximum numbers of roots (4.43) were produced in the MS medium containing $3.0 \mathrm{mg} . \mathrm{L}^{-1} \mathrm{NAA}$ in combination with $0.5 \mathrm{mgL}^{-1}$ BAP. Minimum root number (2)was obtained in the MS medium without any growth regulator (Table 2). NAA alone at concentration of 1.5 and $3.0 \mathrm{mg} . \mathrm{L}^{-1}$ produced 2.03 and 2.13 number of roots, respectively. The MS medium supplemented with 1.5 mg.L-1 NAA in combination with 0.5 mg.L-1 BAP produced maximum root length $(4.20 \mathrm{~cm})$. Minimum root length $3.26 \mathrm{~cm}$ was observed in the MS medium without growth regulator followed by root length of $3.27 \mathrm{~cm}$ in the MS medium supplemented with 1.5 mg.L-1 NAA.

\section{Discussion}

Browning of explant and withering of shoots are among the prominent problems faced during in vitro propagation of $R$. centifolia which were addressed successfully in this study.

MS medium supplemented with activated charcoal and explants placed in running water for $1 \mathrm{~h}$ was found effective for decreasing the browning percentage. Activated charcoal has very fine pores, larger surface area and volume to absorb the phenolic compounds, secondary metabolites that modulate plant development. Sharada et al. (9) found activated charcoal effective against oxidative browning in Celastrus paniculatus and C. orchioides, respectively.

Stirring of explants in solutions of ascorbic acid or citric acid was also found to be effective in the present study and results are supported by $\mathrm{Wu}$ and du Toit, (10) who successfully controlled browning by stirring of explants of Proteacynaroides in ascorbic acid and citric acid solution for $1 \mathrm{~h}$.

We tested effect of different amino acids on axillary bud of $R$. centifolia. Asparagin at $0.09 \mathrm{mg} . \mathrm{L}^{-1}$ produced minimum withering percentage, maximum healthy shooting and took maximum days to show withering of shoots. Haroun et al. (11) noticed an increase in growth with the lower concentrations of asparagine and glutamine in the MS medium in Phaseolus vulgaris. Amino acids are very effective in plant growth because most of the nitrogen is bound up to them. During in vitro propagation, addition of amino acids provides primary fast source of nitrogen supply to plants as compared to inorganic nitrogen. Baker et al. (12) also observed the increase in formation and elongation of cell wall, and cell division due to the addition of amino acids.

Explant that took minimum days to produce shoot, produced more number of laterals shoots and leaves. These results are consistent with the findings of Carelli and Echeverrigaray, (4) who observed that BAP in combination with NAA is very effective for shoot initiation in roses.

Maximum numbers of shoots were produced in the MS medium supplemented with BAP along with NAA. Nak-Udom et al. (13) noted higher shoot multiplication in the MS medium supplemented with 3.0 mg.L $\mathrm{L}^{-1}$ of BAP with lower concentration of NAA. Explants, which had more number of shoot, showed good growth in the rooting and potting media. Shoots with less number of laterals had maximum chance to die.

Higher concentration of BAP with lower concentration of NAA produced maximum number of leaves. The leaves that were remained in the shooting media 
for a long period of time became dry and fell down on the media. Chu et al. (14) also observed that plantlets began to exhibit chlorosis in the $6^{\text {th }}$ week of culture. Shoots with only one or two leaves had maximum chance to die. MS medium without any growth regulator proved the least effective for in vitro shoot formation of $R$. centifolia. Rout et al. (15) noticed that the addition of cytokinin into the MS medium improved the in vitro shoot multiplication of hybrid roses.

NAA in combination with BAP was found very effective for in vitro rooting of $R$. centifolia. These results are related with Sajid et al. (16) who found that NAA along with BAP is more effective for root formation. Explant cultured on the MS medium supplemented with higher concentrations of NAA alone and in combination with BAP also produced callus at lower end of explants. Baig et al. (17) observed callus on the explants cultured on the MS medium containing higher cytokinin concentrations.

\section{Acknowledgements}

The present study was funded by the Higher Education Commission of Pakistan under indigenous fellowship program.

\section{References}

1. Gault SM, Syngy PM. Introduction In: "the dictionary of roses in color." Ebury press and Michael Joseph, Hague. 1971.

2. Narayan DP, Kumar U. Agro's Dictionary of Medicinal Plants. Agrobios India. 2003.

3. Razavizadeh R, Ehsanpour AA. Optimization of in vitro propagation of Rosa hybrida L. Cultivar Black Red. AmEurasian J Agric Environ Sci. 2008;3:96-99.

4. Carelli BP, Echeverrigaray S. An improved system for the in vitro propagation of rose cultivars. Sci Hortic. 2002;92:69-74. DOI:10.1016/S0304-4238(01)00280-1

5. Gitonga LN, Gichuki ST, Ngamau KA, Muigai WT, Kahangi EM, Wasilwa LA, Wepukhulu S, Njogu N. Effect of explant type, source and genotype on in vitro shoot regeneration in Macadamia (Macadamia spp.). J Agric Biotech Sustainable Dev. 2010;2:129-135.

6. Block R, Lankes C. Measures to prevent tissue browning of explants of the apple rootstock M9 during in vitro establishment. Gartenbauwissenschaft. 1996;61:11-17.

7. Skirvin RM, Chu MC. In vitro propagation of 'Forever yours' Rose. Hort Science. 1979;14:608-610.

8. Murashige T, Skoog F. A revised medium for rapid growth and bioassay with tobacco tissue culture. Plant Physiol. 1962;15:473-497. DOI: 10.1111/j.1399-3054.1962.tb08052.x

9. Sharada M, Ahuja A, Kaul MK. Regeneration of plantlets via callus cultures in Celastrus paniculatus Wild-A rare endangered, medicinal plant. J Plant Biochem Biotechnol. 2003;12:65-69. DOI: 10.1007/BF03263163
10. Wu HC, du Toit ES. Reducing oxidative browning during in vitro establishment of Proteacynaroides. Sci Hortic. 2004;100:355-358. DOI: 10.1016/j.scienta.2003.07.007

11. Haroun SA, Shukry WM, El-Sawy O. Effect of asparagine or glutamine on growth and metabolic changes in Phaseolus vulgaris under in vitro conditions. Bioscience Research. 2010;7:1-21.

12. Baker A, Hill G, Parsons R. Evidence of nitrogen feedback regulation of nitrogen fixation in Alnusglutinosa L. J Exp Bot. 1997;48:6774. DOI: 10.1093/jxb/48.1.67

13. Nak-Udom N, Kantamaht K, Kamnoon K. Micropropagation from cultured nodal explants of rose (Rosa hybrida L. cv. 'Perfume Delight'). Songklanakarin J Sci Technol. 2009;31:583-586.

14. Chu YC, Knight SL, Smith MAL. Effect of liquid culture on the growth and development of miniature rose (Rosa chinensis Jacq. 'Minima'). Plant Cell Tiss Org. 1993;23:329-334. DOI: $10.1007 / \mathrm{BF} 00042296$

15. Rout GR, Debata BK, Das P. In vitro clonal multiplication of roses. Proc Natl Acad Sci India. 1990;60:311-318.

16. Sajid GM, Siddique IMK, Rashid A. Effect of diverse hormonal regimes on in vitro growth of grape germplasm. PakJ Bot. 2006;38:385-391.

17. Baig MMQ, Ishfaq AH, Azhar H, Touqeer A, Nadeem AA. An efficient protocol for in vitro propagation of Rosa gruss an teplitzand Rosa centifolia. Afri J Biotech. 2011;10:4564-4573. DOI: $10.5897 / \mathrm{AJB} 10.2051$ 